\title{
PRESBUTEROI CHRISTIANOI: \\ TOWARDS A THEORY OF INTEGRATED MINISTRY ${ }^{\prime}$
}

\section{Stephen Richard North}

This thesis examines how words for Christian leaders of the New Testament period, such as apostle, elder, and so on, were understood by the writers and readers of the New Testament documents, by looking at their usage in contemporary literary and epigraphic sources from the perspective of an ancient historian. Although the need for such examination is placed in the context of various recent debates over such structures and church reunion (for example the Anglican and Catholic document on the authority of the Pope), it was not originally intended to delve into the murky depths of the continuation of apostolic authority after the original generation.

However, as a result of the conclusions of the first chapter, which presents a revised chronology for the New Testament letters, it seemed inappropriate to ignore the discussion of the relationship between the apostolate and the presbyterate. This first chapter deals with the issue of authenticity (predominantly) of the Pauline letters, and recognises that there are schools of thought which question the traditional authorship of the letters and seek to place them either in the late first century or early second. It is stated at the start that such pseudonymity was unlikely. Statistical analysis of word usage is determined as an unreliable source, partly due to methodological errors in some forms of analysis, 'and the fact that the letters were written to different situations and people; this may account for apparent differences. It is concluded that authorship can only be disproved if the letters cannot be fitted into specific historical situations, and the remainder of the chapter looks at this question. To summarise the conclusions of this chapter, it is argued that all the canonical New Testament documents date prior to the fall of the

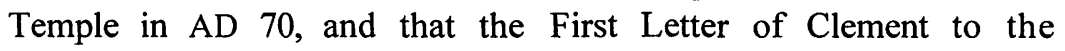

1 Stephen North, Presbuteroi Christianoi: Towards a Theory of Integrated Ministry (unpublished Ph.D. thesis, University of Wales, Swansea, 1999); supervisors: Dr D.W.J. Gill and Professor S. Mitchell. 
Corinthians should also be placed prior to this event. It is also suggested that the only reasonable date for the writing of 1 Timothy and Titus is shortly after 1 Corinthians, for which the traditional date is accepted. This dating brings into question the idea of the development of the ministry, a question which is returned to in Chapter 7.

Chapters 2-6 discuss the usage of the words apostle, teacher, overseer/bishop (episkopos), elder and prophet respectively in the New Testament period, by examining the words in their Greek setting, their Jewish setting, and finally their church setting, and seeing what influence each of the first two had on the third. The word apostle is particularly hard to understand, since the vast majority of the references to the word occur in the New Testament, and most of the non-New Testament occurrences appear outside the first century $\mathrm{AD}$. After examining the sparse Jewish and Greek references to the word, an excursus examines the question as to whether the term was coined in Antioch, and concludes that it is probably a translation of the Hebrew $\breve{s} \bar{a} \bar{I}^{\bar{a}} \mathrm{~h}$, a legal (not religious, although it is used in such contexts) term meaning 'a man sent is as the person himself'. The analysis of New Testament usage is conducted with particular reference to this viewpoint, and concludes that the Christian apostolate completely fits the $\breve{s} \bar{l} l \bar{l}^{a} h$. While arriving at this result, it is argued (contrary to the majority viewpoints) that Paul was not commissioned an apostle of Christ on the Damascus Road but rather in Antioch (Ac. 13:1-3), and that the reference here is not to a missionary apostolate; that there is no basis for believing that Luke confined the apostolate to the Twelve; that the apostles are not necessarily channels of revelation. It is also argued that the temporary nature of the $\breve{s a} l \bar{i}^{a} h$ is well fitted to the New Testament apostle, given the contemporary belief in an imminent return of Christ.

In chapter 3 , it is argued that the teachers in the church were responsible for the passing on of information, and that the word can be understood both as a function and as an office, although not all those who regularly taught were teachers in the sense of an office. Chapter 4 looks at the role of the episkopos, and it is argued that the word denotes a member of the church with the added responsibility of ensuring order in the house-churches. It is concluded that the origin of the term is not with the Greek cults, and that there is no evidence to deny the presence of the episcopate in the Jewish Christian communities in Palestine, which also suggests that any 
influence upon the Christian usage comes from such people as the Qumran mebaqqer. It is also argued that 'the bishop' of 1 Timothy and Titus refers not to the later monarchic episcopate, but to a presiding bishop, a 'first amongst equals'. Chapter 5 examines the presbuteros, the elder. It is determined that there is no evidence for the use of the word as an office among Greek political institutions, but on the basis of the Egyptian papyri, and later epigraphy, that the word might possess such an implication in villages in Greece. Again, however, the influence in Christian usage comes from Judaism, where it is a title of respect given to leaders among the community, denoting their personal qualities for the task. Chapter 6 looks at the prophet, and it is again concluded that the term is used two ways. It normally refers to those who have special revelations and understanding, but can also be used to in the sense of an office. During these discussions, the confusion about the presence of the Holy Spirit in Second Temple Judaism is noted, and it is also argued that the reference to the silence of women (1 Cor. 14:34b-35) is best understood as a false prophecy which Paul corrects.

Chapter 7 picks up the question of the development of the ministry in the light of the new chronology, and discusses the evidence for early dates for the offices of deacon, elder and bishop on their own merits. Lightfoot's 'Excursus on the, Christian Ministry' (from his commentary on the letter to the Philippians) is then examined as representative of development theories, and it is demonstrated that the excursus has several internal inconsistencies, even without the new chronology. The evidence of the Didache also shows that the transition from the apostles-prophets-teachers structure to that of bishops-elders-deacons was only taking place in the late first century.

In view of this, chapter 8 asks whether there is any evidence for two views. Firstly, Harnack's idea that the apostles, prophets and teachers were itinerant is examined and rejected. Secondly, the view that apostles and prophets were intended to be a limited, first generation only, ministry according to the New Testament records is examined and, again, rejected. In the course of this discussion, it is argued that the description of the apostles and prophets as 'foundations' (Eph. 2:19-22) cannot be interpreted to make the apostles limited to writers of Scripture. It is also demonstrated that interpreting 1 Corinthians 15:8 to make Paul the last apostle is neither contextually nor exegetically possible. Rather, it is argued that 1 Clement 44 retains evidence of a codicil to the apostolic teaching 
which allowed for the appointing of further apostles as the need arose. It is then argued that Apollos, Silas, Timothy and Clement of Rome were all apostles of Christ.

In light of the evidence it is concluded and argued in chapter 9, that the two supposedly separate ministries should in fact be seen as one group, and a theoretical model for the new relationships is proposed.

An appendix argues that the verses in 1 Corinthians 11 which supposedly command women to cover their heads in church originate from the Corinthians, a position which Paul rebuts in verses 11-16. 